\title{
Making biodiversity work for coffee production. A case study of Gayo Arabica coffee in Indonesia
}

\begin{abstract}
Biodiversity is defined as the variety of life encompassing the 'existing' variations at all level, starting from the tiny genes within a species up to a broader sense consisted of habitats within ecosystem. It is urgently needed as long as human is still exist on this earth. Therefore, its proper utilization and correct application of biodiversity bring great advantage in tangible and non-tangible benefits. Indonesia is known as the third largest biodiversity hotspots; both its flora and fauna. It has also tremendous diverse ecosystems extended from west to east; with amplitude of variation ranging from humid tropical rain forests until a very dry savannah type at the eastern part of Nusa Tenggara. Furthermore, Indonesia is also known as the fourth world highest producer of coffee; with a total production 11,49 million $\mathrm{kg}$ in 2016-2017. The Gayo highlands on the northern tip of Sumatra are known as the major production of arabica coffee. There, up to ten varieties of commercial arabica coffee are planted on the highlands. The origin of coffee is in Ethiopia, which is believed as the center of the commercial coffee species in this world: C. arabica and C. canephora. The objective of this paper is to review the status of coffee, esp. the arabica one from various perspectives, ranging from the biology, history of coffee, the processing of coffee (wet $v s$. dry methods), and how the component of natural biodiversity can be applied in order to enhance the coffee production, particularly on the Gayo highlands.
\end{abstract}

Volume 6 Issue 4 - 202I

\author{
Rita Andini,' Murna Muzaifa, ${ }^{2}$ Leni Marlina, ${ }^{3}$ \\ Muhammad Ikhsan Sulaiman, ${ }^{2}$ Rachman Jaya, ${ }^{4}$ \\ Ali M Muslih,' Heru PWidayat ${ }^{2}$ \\ 'Forestry Department, Faculty of Agriculture, Universitas Syiah \\ Kuala (USK), Indonesia \\ ${ }^{2}$ Agricultural Product and Technology Department, Faculty of \\ Agriculture, Universitas Syiah Kuala (USK), Indonesia \\ ${ }^{3}$ Vocational Department in Secretary, Faculty of Economy and \\ Business, Universitas Syiah Kuala (USK), Indonesia \\ ${ }^{4}$ Badan Pengkajian dan Penerapan Teknologi (BPTP), Indonesia
}

Correspondence: Muhammad Ikhsan Sulaiman,Agricultura Product and Technology Department, Tgk. Hasan Krueng Kalee No. 3, Darussalam, Banda Aceh, 23I I I, Indonesia,

Tel +62813 70504702,Email ikhsan.sulaiman@unsyiah.ac.id

Received: July 18, 2021 | Published: August 06, 2021

Keywords: aceh, Arabica, livelihoods, sustainable

\section{Introduction}

Biodiversity is defined as the variety of life encompassing the 'existing' variations at all level, starting from the tiny genes within a species up to a broader sense consisted of habitats within ecosystem. This includes all natural elements e.g. plants, wildlife, unseen living things, such as microorganisms. ${ }^{1}$ A proper utilization and correct application of biodiversity bring great advantage not only in terms of tangible benefits (e.g. livelihoods or financial sector, economic developments, ecosystem, food and nutritional securities), but also to the intangible ones (e.g. human-, and mental health, cognitive-, psychological-, and physiological development, as well as the interaction between biodiversity $v s$. human health). In short, a properly functioned biodiversity would not only support its major actors (plant, human, and wildlife) per se, but this also serves as the major key for a well-functioned human-natures interaction on earth. Therefore, systematic and sustainable approaches to observing, monitoring, and bringing each function properly in biodiversity across all levels (genes, species, habitats, ecosystems) are urgently required.

Indonesia, the world widest archipelago (latitude $5^{\circ} 00^{\prime} \mathrm{N}$ and longitude $\left.120^{\circ} 00^{\prime} E\right)^{a}$ and occupying $1.3 \%$ of the world's land surface is known as one of the megadiversity countries. The biodiversity richness of Indonesia accounts about $12 \%$ of the total mammal species; 35 primate species, while 18 of which are endemic; $7.3 \%$ of the total reptile species; $17 \%$ of the total bird species; 270 species of amphibians; and 2,827 invertebrate species. Such magnificent diversity is also supported with a tremendous diverse of ecosystem extended from west to east, in which 90 types are exist; ranging from the humid tropical rain forests, sub-tropical highland altitudes, up to a very dry savannah type at the eastern part of Nusa Tenggara with an average temperature is ranging from $23^{\circ} \mathrm{C}$ until $38^{\circ} \mathrm{C} .^{2}$ Furthermore, it is being estimated that more than $50 \%$ of Indonesia's plant species inhabiting the tropical rain forests, have not yet been fully discovered and properly recorded, including those inhabit the Sumatran rain forests.

Other than being known as one of three biggest mega-biodiversity hotspots, Indonesia is also known as the fourth largest producer of coffee in the world with total production up to 11,49 million $\mathrm{kg}$ noted in 2016-2017. Although, the center of origin of coffee is on the highlands of Ethiopia according to Vavilov, it has been widely introduced, distributed, and cultivated almost on three continents: Latin America, Africa, and Asia. This commodity is the second most traded ones after crude oil where coffee bean is exported from the developing countries to the industrialized ones, with a business worth more than US $\$ 12 * 10^{9}$ values. ${ }^{4}$ At least 20 million famers and millions of other segments along the coffee supply value chain are being involved. For them, the craft and science of coffee go hand in hand, although as an agricultural crop, coffee plant is naturally subject to weather conditions and diseases. ${ }^{5}$ The purpose of this paper, therefore, is to review our understanding of coffee production especially the arabica one in Indonesia, and how the biodiversity richness of Indonesia can be targeted to secure the coffee plantation that has been served as a pivotal income for most of small holder farmer under the climate change threat.

\section{Results}

Drinking coffee has been served as an 'icon' of a modern lifestyle in most of big cities across the globe and is a pre-requisite as daily stimulant booster, or as refreshing agents especially at mornings or afternoons. For some people, coffee is a kind of an 'elixir' in a cup, that could bring people together, fostering communication as well as to improve their working productivity. Drinking a cup of coffee not only stimulates our mind and well-being, but also keeps us healthy due to antioxidants and secondary metabolites e.g. chlorogenic acids. ${ }^{6}$ 
One single coffee-fruit or 'cherry' consists of outer skin, pulp, pectin layer, parchment, and silver skin, while the part that is being consumed and traded is 'actually' the bean or endosperm. The bean form is elliptical or egg-shaped, plane-convex, and has a kind of longitudinal furrow on the plane surface and the bean quality is very important for further determination of the taste. The outer cover of the bean is covered by a hard pale brown endocarp that becomes the 'parchment' after drying. Meanwhile, the endocarp contains an enclosed seed, that has a thin, green testa known as the spermoderm or also referred here as 'silver skin'. This is actually the remnant of the perisperm (Figure 1). Coffee trees differ greatly in morphology or phenotype, size and ecological adaptation, in which all of these lead to the description of a diverse number of species. Phylogenetically, coffee belongs to the sub-genus classified in the Rubiaceae family, which includes 640 genera and about 10,000 species (Figure 1). There are 70 species exist, however, only two species are attributed with economic importance, they are: Coffea arabica L. ('arabica') and Coffea canephora Pierre ('robusta').
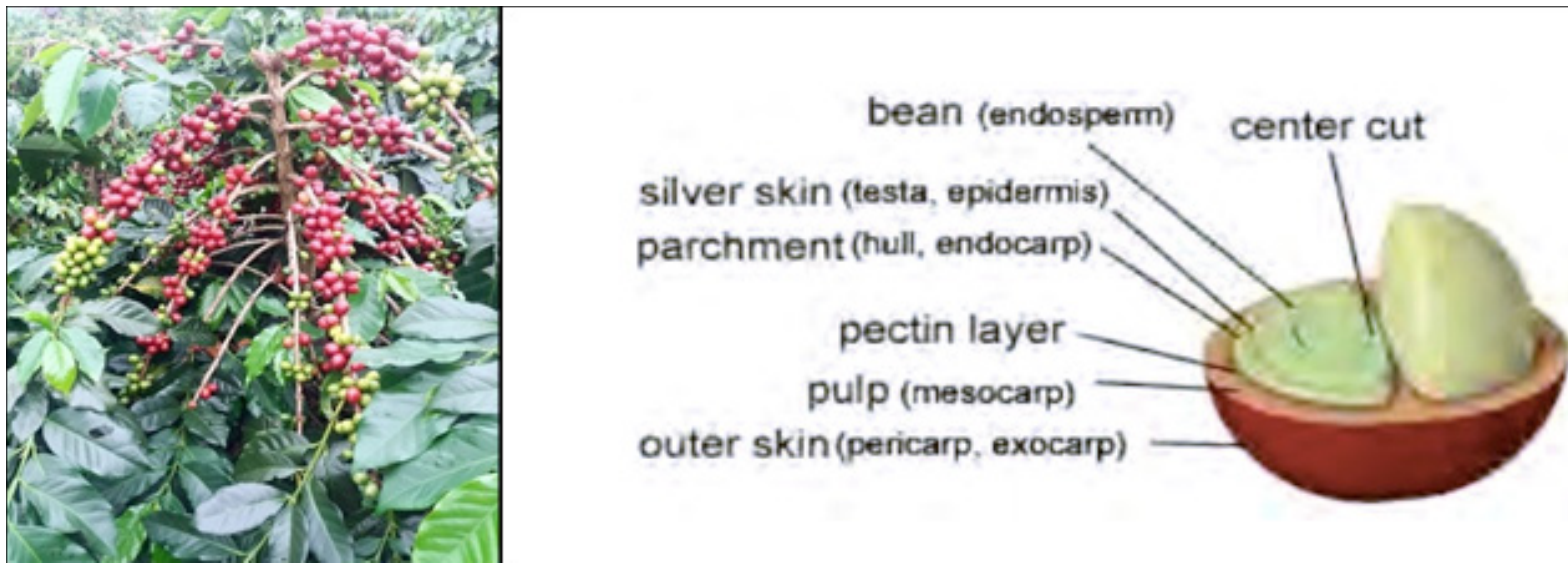

Figure I The coffee berry (left), the main component of coffee cherry (after Mirian et al. $\left.{ }^{3}\right)$ (right).

Arabica coffee is the only allotetraploid with chromosome number $(x=11)$, which is formed via the hybridization or introgression between two diploids: C. canephora x $C$. eugenoides, self-fertile, better adapted to highlands, usually graded as 'high' quality, milder taste, and its bean sizes are usually bigger than robusta due to the polyploidy state ${ }^{3}$, but it is known to be more susceptible to major diseases of coffee, esp. leaf rust. ${ }^{3}$ Meanwhile, C. canephora or also known as 'robusta' is more indigenous to tropical African forests covering a large area ranging from West Africa, central, until the northern Angola and Tanzania, which corresponds to hot and humid tropical climatic regions. Its range of production mostly found in low and middle altitudes regions of Africa. Although it has more inferior cup quality, the plant is more robust against major attacks of diseases and insect pest.

\section{Coffee from gayo highlands in Indonesia}

Indonesia is bestowed with a climate varieties that are suitable for coffee plantation and it serves as the fourth biggest coffee producing countries in the world. Its total number of production amounts at 790,000 tons and coffee is classified as one of the important key commodities. Up to $71 \%$ of coffee produced in Indonesia is being exported to the global market, with 'robusta' as the major commodity (up to $73 \%)^{7}{ }^{7}$ Currently, up to 1.3 million hectares of coffee plantation is being noticed. Initially, the Dutch via the 'Vereeiniging Oost Indische Compagnie' (VOC) pioneering the plantation in late $17^{\text {th }}$ centuries on Java island. After a success first export in 1711 from Java, they expanded outside Java such as on Sumatera, Bali, Celebes, and even to East Timor (currently a neighboring country). Since 1920 or other source mentioned 1924, the Dutch established a center of arabica or the high quality one at the north of Sumatra. Since then, almost $74.2 \%$ of coffee has been originated from Sumatra (Figure 2). ${ }^{8}$
In Indonesia, generally, there are three types of coffee being grown. They are: arabica, robusta and liberica. Arabica requires higher elevation over than $1,000 \mathrm{~m}$ a.s.l., with a relatively high precipitation between $2,000-3,5000 \mathrm{~mm}$ yearly, and dry month with a maximum of three months, and precipitation amount less than $60 \mathrm{~mm}$ monthly. Meanwhile, robusta requires less precipitation ranging from 1,500 $-3,500 \mathrm{~mm}$ yearly with an elevation ranging from $40-900 \mathrm{~m}$ a.s.l. The liberika requires a quite low altitude higher than $20 \mathrm{~m}$. a.s.l. and precipitation amount of 2,000-2,500mm yearly. Depending on which varieties that are already adapted with particular ecosystem, diverse agricultural management is also applied.

The province of Aceh is known as the most extensive arabica coffee plantation in Indonesia, with almost 101,316 hectares and total amount export from this region could reach $28,32 \%$ or equal to 66,942 tons. In Bener Meriah with $53 \%$ of the total arabica coffee plantation, then followed with middle Aceh are the two most distinct coffee plantation areas. The productivity is noted between $700-800 \mathrm{~kg} \mathrm{ha}^{-1}$ (average $=790 \mathrm{~kg} \mathrm{ha}^{-1}$ ) and almost $80 \%$ small holder farmer owning their own land are being involved in the supply chain management or businesses. In total, there are up to ten varieties of arabica planted on the highlands, they are: "Timtim Aceh", "Borbor", "P 88","BP 542 A", "Ateng Super" and other two local 'novel' lines referred as: "Ateng Jaluk" and "Ateng Janda"; with the last is recently booming and cultivated at high altitude regions above $1,280 \mathrm{~m}$ above sea level (a.s.l.). On the Gayo highlands, previous favorite lines planted by most of farmer in 1980-1990's were "S-Line" and "Catimor var. Jaluk". However, these were strongly damaged by leaf rust and root disease. ${ }^{9}$ Therefore, the core collection being preserved in the forest arabica coffee population in Ethiopia is important for the improvement of the crop, particularly against pest and diseases' attack. 


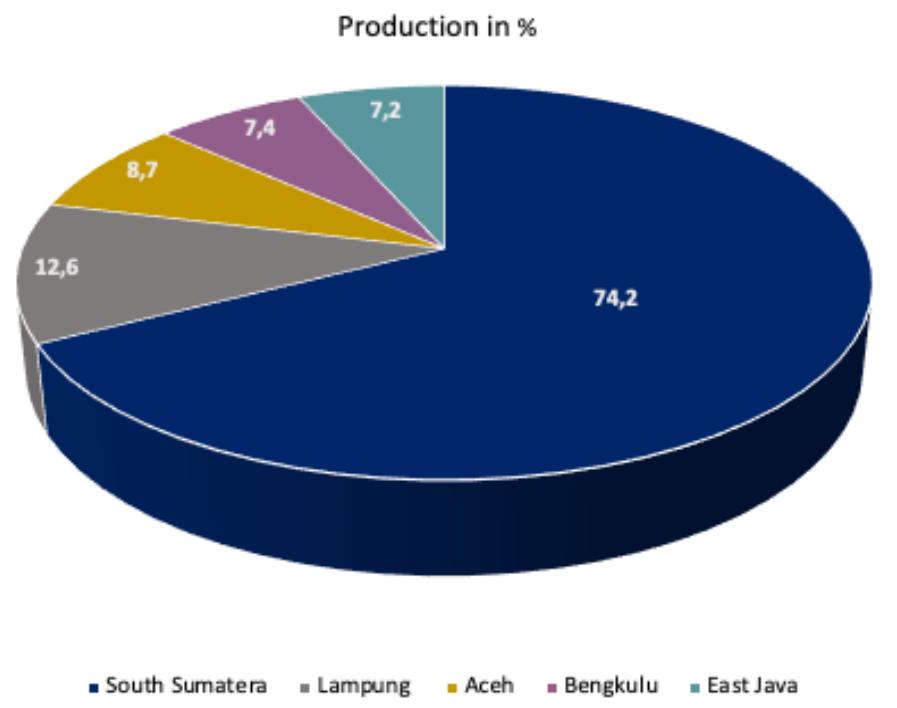

Figure $\mathbf{2}$ The percentage of coffee production from various provinces in Indonesia, source. ${ }^{8}$

Since 2000, the taste of arabica 'Gayo' has been noted as one of the best specialty one in the world and this might be the result of many factors, e.g.: the varieties of coffee 'themselves' likewise 'Timtim Aceh', 'Borbor', 'P 88', 'BP 542 A', and 'Ateng Super', planted on high elevation ( $900 \mathrm{~m}$. - 1,700 m. a.s.l.), 1,643-2,000mm of precipitation per year, soil interaction, and special techniques applied during post-harvest. The quality of coffee depends strongly on species and geographic origin, the inter-action between the two factors ${ }^{6}$ particularly the coffee processing. In general, there are two main types of coffee processing techniques, they are: 1) wet type, 2) dry type; while the first is presumed to be much better in terms of bean quality but due to its higher cost only companies or real enterprises such as farmer cooperation applies that one (Figure 3). The second method is commonly applied by many small holder farmer or by farmer living on areas with water scarcity but in Indonesia, this kind of method is applied for beans with low or degraded quality, e.g. half mature or over mature.

\section{WET METHOD}

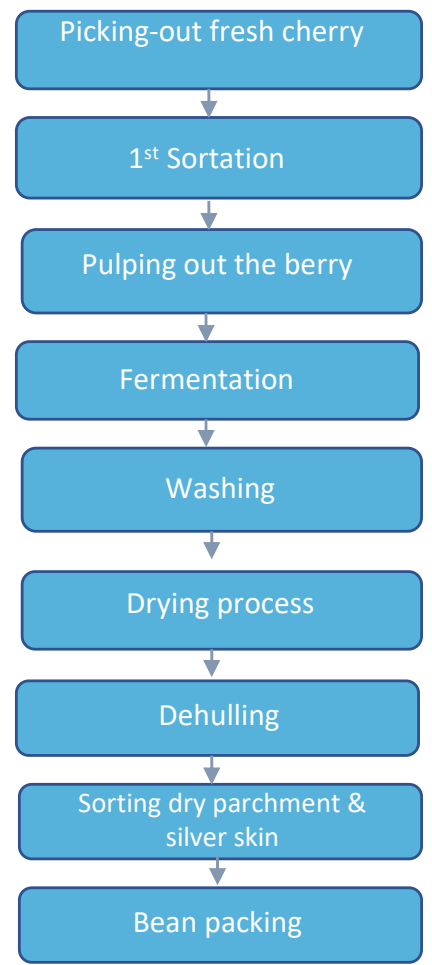

\section{DRY METHOD}
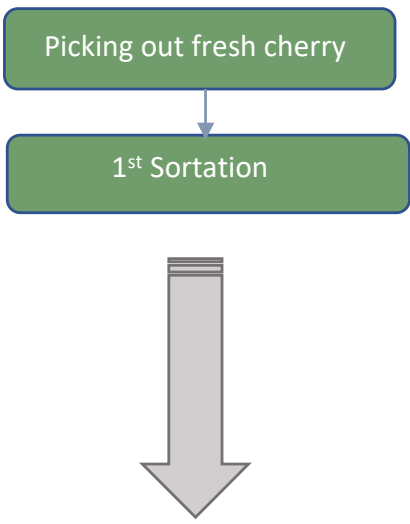

Drying process

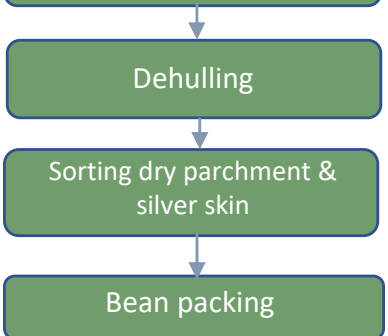

Figure 3 The two common types of coffee processing, after. ${ }^{9}$ 
The difference between the two types is due to water application during the peeling of outer skin and fermentation process (Figure 3). Nevertheless, the combination of both processing types is also applied in some cases. The transformation of coffee cherries into clean, green bean of $12 \%$ moisture ready for export and roasting depends on a scrutinize and careful processing; starting from harvesting and picking the mature cherries, pulping, fermenting, washing, drying, hulling or sometimes called as 'dehulling', cleaning, grading, sorting, storing, and transporting green beans. It is necessary to realize that each of these steps has an in-/direct influence on the final quality of coffee produced at the end. The process of any agricultural products, generally, continuous chain activities aimed at achieving a coffee of high quality. If any disturbance or retarded process intervenes the 'link', e.g. over fermentation, mold contamination, taints or odors, or any physical damages to the bean), then the quality loss would affect the final profit from the selling. ${ }^{10}$ Therefore, a careful notice during the processing is taken into account by many of coffee farmer. Each processing step is clearly described in Winston et al. ${ }^{10}$

Particularly, for those coffee farmer on Gayo highlands, whose coffee production almost $75 \%$ is intended for the export, and the majority of farmer has been 'ever' involved by the international certification bases e.g. 'Organic Certified', 'Fairtrade', and 'Rainforests', which are majorly intended for increasing the income of farmer in those regions. ${ }^{11}$ Indeed, such labelling at the European and U.S. market 'niche' has helped the majority of farmer to increase their income by achieving the so called 'premium price' from selling the arabica coffee at the world trade. The price is tendentially increasing at $1,73 \%$ per annum, which is accompanied by an increase price up to ten times higher at the higher level, or at global trade. Unfortunately, such relatively high benefit at the global trade level has not yet reached to the 'grass-root' level. It seems that there is a kind of 'asymmetrical' market disorder between the attained price at the 'grass-root' vs. at the global level as a result of many factors, such as: very limited infrastructures and physical facilities, access to financial capital, and the most important is the access to market information. ${ }^{7}$

\section{Current constraints regarding coffee cultivation}

The major constraints in coffee are pest and diseases are caused due to insect pests, bacteria, fungi, and viruses. Table 1 describes in general those kinds of risk attacks.

Table I Various 'common' attacks of pests and diseases in Coffea spp. based on Winston et al'

\begin{tabular}{lll}
\hline No. Item & Information \\
\hline A. Insect Pests & \\
& \\
& $\begin{array}{l}\text { It is common and a serious problem. } \\
\text { Scales could reduce growth and } \\
\text { crop yield. In general, there are two } \\
\text { types of green scale, first (C. viridus) }\end{array}$ \\
& $\begin{array}{l}\text { is commonly found at the elevation } \\
\text { below I,200 m a.s.l., while C. alpinus is } \\
\text { found above that level }\end{array}$
\end{tabular}

Aphids can occur in large number usually in the rainy season. They can be found on new shoots and cause damage to these developing shoots as they suck sap from the young shoots.

The red ones are usually found in the upper part of coffee trees and they make tunnels through the coffee branches. Branches at the top part of the main stem can easily break off but the main bark of three usually survive.

\section{Measurements}

2

Aphids (Toxoptera aurantii)

Stemborers, there are two types: a) Red

3 stemborers (Zeuzera coffeae), b) white (Xylotrechus quadripes).
The white one, meanwhile, is I to $2 \mathrm{~cm}$ long and the adults are active during day light. Damages are caused by the white larvae, which hatch from eggs deposited in cracks, under loose scaly bark of the main stem and thick primary branches, esp. on plants exposed to sunlight.
By spraying chemicals, if 10 or more leaves are being infested with one or more scales. A traditional option is to spray weekly a combination between strong tobacco, water, then soaking it for $2 * 24$ hours, afterwards, washing powder is being added.

Chemicals bought from the market or by spraying the leaf surface (top- and underside) of leaves and developing shoots by using traditional 'mixture' between neem oil plus finely grated laundry soap.

Higher altitude seems to impede the incidence of infestation. Good shade can also reduce the damage occurred.

\section{Do not plant trees with twisted} taproots. Such deformed roots result in weak tress that have been shown to have a higher incidence of stemborer infestation.

Either biological or chemical substance is being known to effectively control this stemborers. 
Table Continued...

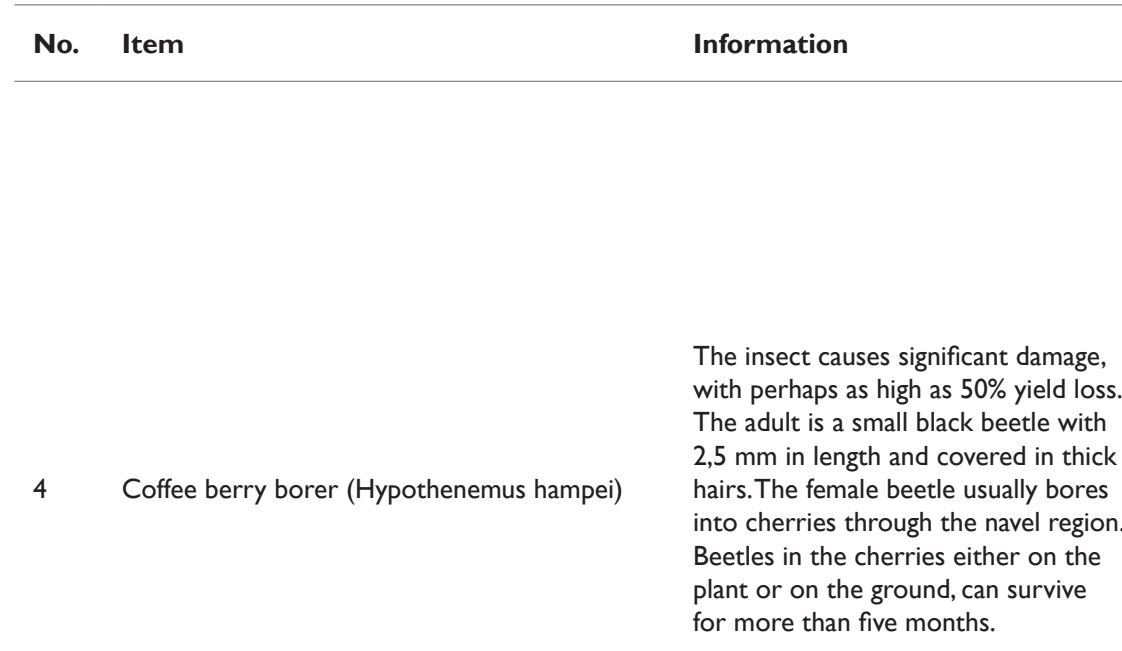

\section{Measurements}

Orchard hygiene is obligatory, such as: i) keeping the area clean, ii) removing dropped cherries, iii) removing carryover fruit from coffee bushes are suggested as cherries on the ground and old berries remaining on threes are a source of new infection.

A proper quarantine, as well as careful drying of coffee cherry or parchment could also reduce the reproduction of the pest as they cannot survive in coffee beans that are properly dried to $12 \%$ moisture.

Biological or natural borers' enemies can be , e.g. a kind of wasp (Phymastichus coffea). Chemical control is rather difficult as the borer spends most of its life cycle deep inside the coffee cherry.

They are small sucking insects - about $3 \mathrm{~mm}$ long, covered with a white mealy wax that feed on young shoots and young roots. They are generally more a problem in the dry season when water is lacking. Nevertheless, serious infestations of mealybug are often found where there has been use of insecticide sprays, esp. high toxic organo-phosphate sprays as these kill not only the mealybugs but also their natural enemies.

\section{B. Diseases}

I Damping off

\section{Carcospora leaf spot}

This disease occurs on young coffee seedlings in the nursery in the germination bed, after germination, and before transplanting. It is caused by fungi: Phytium spp. There are various factors of the fungi: a) soil borne fungi, b) soil is too wet, c) too much shade, d) high planting density

It is a kind of fungus that occurs on leaves when plants are under stress. The fungus can develop both in seedbeds and after plants have been transplanted into bags. It is the most common nursery disease and a sign of poor management. Spots can be found on both sides of the leaf, when too many spots, leave appear to have been burnt.
Biological or natural predator would usually be sufficient as the most important predator is the ladybird (Cryptolaemus montrouzieri).

Prevention: do not use old soil from nursery beds or bags as disease is soil borne and can be transmitted.

Prevention: avoid over watering, maintain $50 \%$ shade cover, space plant bags to allow air movement. Proper fertilizer application.

Chemicals may be also applied such as: Copper sprays consist of : copper cupravit, copper oxychloride, and copper hydroxide. 
Table Continued...

No. Item
Information

It occurs on leaves and in severe cases can cause leaf drop. The first symptoms is the formation of pale yellow spots up to $3 \mathrm{~mm}$ in diameter on the underside of the leaves. As the spots expand, they become powdery and yellow to orange in color and may reach $20 \mathrm{~mm}$ in diameter. Occasionally, the whole leaf becomes covered with rust spots. Older rust spores become brown at the center surrounded by powdery orange spots. Leaf drop occurs, and in the worst case can lead to dieback and cherry loss and loss of both yield and quality.
Measurements
3

Coffee leaf rust (Hemileia vatatrix)

C

Plant Disorders

I Overbearing or dieback
This is not a 'true' disease but a physiological problem, which is indicated with severe leaf loss and branch die back. Plants usually decline and eventually die if the problem is not corrected in early stages.
Some varieties, e.g. Java, Typica and many other Arabicas are susceptible under poorly shaded conditions and altitudes of less than I,000 m.

Prevention: planting 'Catimor' variety or other more tolerant varieties and follow the recommended nutrition program. Plant pure arabica at high elevation only, and always use good shade.

Chemicals: monthly copper sprays are recommended.
Coffee needs one leaf pair to support five to six berries through to maturity. If there are too many cherries and not enough leaves to support, then all the food goes from the leaf to the developing cherry. Leaves then drop off and cause die back. Loss of leaf depletes plant carbohydrate reserves resulting in weakened plant.

There is no exact cure, as once the problem exists it is very hard to break the cycle if it is left too long. Therefore, maintaining a good plant health is necessary.
The component of natural biodiversity can be applied in order to enhance the coffee production, particularly the Gayo coffee production in Indonesia. Using the natural enemies or predator or also known as the Integrated Pest Management (IPM) is an effective method to control many problem insects without bringing an adverse effect to our environment. Up to now, we still do not own the full range and degree of activity of predators but preliminary studies have indicated that the presence of a number of predators with spiders; e.g. wolf spiders (Lycosa spp.), dwarf spider (Atpena spp.), as well as other flies, wasps and diverse kinds of insects could be applied as natural predators being in common. ${ }^{10}$

Other than pest and diseases' problems, coffee productivity is always an interesting parameter to be increased and set as one of the important breeding targets. So far, the intention of many breeders are to transfer the gene resistance against abiotic and biotic stresses, resistance against nematodes, tolerant to marginal or, drier land, efficient use of natural soil nutrition without adversely intervening cup quality of $C$. arabica despite the ploidy difference constraints ${ }^{12,13}$ is the major intentions. The gene resistance is usually contained in the wild species (C. congensis, $C$. dewevrei, $C$. racemosa) but they usually have different set of chromosome. Therefore, gene recombination or artificial introgression can be used as effective tools in order to overcome the genetic constraints.
Despite its extra ordinary taste and flavor, the productivity of the current yield of the coffee from Gayo highland in Indonesia, is still considered low. This could potentially be increased up to 2 tons of green beans per hectare per annum. In order to breed new variety with high yield, exploring the genetic variability of Coffea spp. is an inherent and essential capital. Variability is termed as the occurrence of differences among individuals due to differences in their genetic composition and/or the environment in which they are raised. Genetic variability, is the core of plant breeding because proper management of diversity can produce permanent gain in the performance of one plant in general and can buffer against seasonal fluctuations, including the abiotic and biotic stresses. Such genetic variations can be classified at three levels: a) species, b) population, c) individual levels. ${ }^{14}$ Ethiopia is known as the centers of origin and diversification of C.arabica, there, a high genetic diversity of arabica must be exist than anywhere can be found in the world. Based on several phenotypic and molecular studies, it was revealed that the populations of $C$. arabica from the southwestern part have high genetic variability and the forests are, therefore, suitable for in-situ conservation of the species. The variation existing there is higher if it is compared to cultivated populations of the species from around the world. This was being confirmed from a study of genetic diversity among $49 \mathrm{C}$. arabica accessions from Limu, as well as among $100 \mathrm{C}$. arabica accessions collected from Hararghe, 
in Ethiopia. Any breeding techniques, both traditional crossing (crosscombinations) or even gen-recombination that are applied in order to combine the desired gene should be urgently further applied in order to enhance the coffee productivity on Gayo highlands.

\section{Conclusion}

Coffee is the second most drinking liquid after water and drinking coffee has been served as a life style for urban and modern people. Despite a huge species varieties exist in Coffea spp., there area only two considered as the most commercial type : C. arabica and C. canephora or also known as robusta. This review presents about the importance of biodiversity (natural predators, genetic variability existed in Coffea spp.) in order to increase the productivity of coffee production, particularly on the Gayo highlands in Aceh, Indonesia.

\section{Acknowledgments}

Author are grateful to the Lembaga Penelitian dan Pengabdian Kepada Masyarakat (LPPM), grant contract No. 376/UN11/ KPT/2021 declaring the University Advanced Research with the title 'Improving the Quality of Gayo Coffee (Coffea spp.) from Aceh via Genetic Assessment and Sensory'.

\section{Funding}

None.

\section{Conflicts of interest}

All author listed here declare no conflict of interest exists.

\section{References}

1. Sandifer PA, Sutton-grier AE, Ward BP. Exploring connections among nature, biodiversity, ecosystem services, and human health and wellbeing: Opportunities to enhance health and biodiversity conservation. Ecosystem Services. 2015;12:1-15.

2. Sutarno. Global warming and loss of biodiversity. Proc Soc Indon Biodiv Int Conf. 2012;1:4-11.
3. Eira MTS, Silva EAA, Castro RD De, et al. Coffee seed physiology. Brazilian Journal of Plant Physiology. 2006;18(1):149-163.

4. Rukmana R. Keragaan kopi nasional. IUntung Selangit Dari Agribisnis Kopi, 1st edn. Yogyakarta: Lyli Publisher; 2016:17-36.

5. Craft T, Coffee S. The craft and science of coffee go hand in hand, although as an agricultural crop, coffee plant is naturally subject to weather conditions and diseases.

6. Wei F, Miyakawa T, Tanokura M. C-13 NMR-based metabolomics for the classification of green coffee beans according to variety and origin. $J$ Agric Food Chem. 2012;60(40):10118-1025.

7. Putri MA, Fariyanti A, Kusnadi N. Market structure and integration of Arabica gayo coffee in Indonesia. 2013;(1986):47-54.

8. Prasetya E, Roesma DI, Andalas U, et al. Molecular identification of coffee (Coffea arabica) pollinator insects in North Sumatra, Indonesia based on designed COI primers Molecular identification of coffee (Coffea arabica) pollinator insects in North Sumatra, Indonesia based on designed COI primers. Biodiversitas Journal of Biological Diversity. 2018;19(5).

9. Dani D, Rokhmah DN, Pranowo D. Early identification of morphophysiological character differences between four cultivars of Arabica coffee. 2019;6(3):119-126.

10. Winston E, Laak J Op De, Marsh T, et al. Arabica coffee manual for Myanmar a rabica coffee manual for Myanmar. 2005. 96 p.

11. Jumhawan U, Putri SP, Bamba T, et al. Quantification of coffee blends for authentication of Asian palm civet coffee (Kopi Luwak) via metabolomics: A proof of concept. J Biosci Bioeng. 2016;122(1):79-84.

12. Biotechnology PC, Gichimu BM. Genetic characterization of arabusta coffee hybrids and their parental genotypes using molecular markers genetic characterization of Arabusta coffee hybrids and their parental genotypes using. IK Press; 2014.

13. P\&C Research, Indonesia. Genetic diversity of indonesian coffee and its adaptations in different ecosystems. 2020;62(90).

14. Alemayehu D. Review on genetic diversity of coffee (Coffea arabica L.) in Ethiopia. International Journal of Forestry and Horticulture. 2017;3(2):18-27. 